\title{
Andragogy and Female Genital Mutilation in Osun State, Nigeria
}

Ologan Eloho Ukochovwera

M.Sc. of Education in Social Studies, Ekiti State University, Nigeria

Type of article: Original

\begin{abstract}
Background: Although inconspicuously, female genital mutilation (FGM) continues to remain in Nigeria over time.

Objective: This study aimed to throw more light on the traditional practice of FGM in the Osun State in Nigeria while recommending campaign methods and education as the best approaches to raise awareness about FGM risks.

Methods: This cross-sectional study was conducted on 371 rural and urban women. A researcher-made and selfadministered questionnaire coupled with theoretical research were used to collect data on the andragogy for FGM. Data were analyzed using descriptive statistics, Pearson product-moment correlation, and independent samples t-test in SPSS20. The reliability of the instrument was acceptable based on the Cronbach's alpha of 0.79.

Results: according to the results, $64.2 \%$ of the participants reported the practice of FGM in their communities. The study found significant relationships between FGM and health campaign level $(\mathrm{p}<0.0001)$, media campaign level $(\mathrm{p}<0.0001)$, and educational level $(\mathrm{p}<0.0001)$. However, there was no significant difference between FGM practices in urban and rural areas $(\mathrm{p}=0.631)$.

Conclusion: Governmental organizations and NGOs are recommended to take required measures to curb traditional practices, such as FGM, which are detrimental to one's health.

Keywords: Female genital mutilation, Media campaign, Andragogy, Parents education, Adult education, circumcision
\end{abstract}

\author{
Abbreviations / Acronyms: \\ DHS: Demographic and Health Survey; FC: Female Circumcision; FGC: Female Genital Cutting; FGM: Female \\ Genital Mutilation; QAFGM: Questionnaire on Andragogy and Female Genital Mutilation
}

\section{Introduction}

The traditional practice of partial or total removal of external female genitalia is known as female genital mutilation (FGM). It is also known as female circumcision (FC) or female genital cutting (FGC). According to Shetty Priya in the World Health Organization (WHO) bulletin (1), this practice is customary and a violation of the human rights of both girls and women. In regions where statistics are available, half of the girls are cut or circumcised before the age of five (2). The conventional methods used in different regions or ethnic groups are in form of the clitoridectomy, excision, or infibulation (3). As of 2010, infibulation was used on $20 \%$ of women who had been circumcised (4). Culture has made FGM seems like a matter of honor and attributes failing to circumcise one's daughters and granddaughters to promiscuity, or even social exclusion (5). Over time, there have been arguments for and against raising awareness of FGM by the human rights perspective border on the universality of human rights and the cultural relativism as to establish whether the education was utile or it was better to leave people with their cultural beliefs (6). Owing to urbanization and technological advancement, education is considered extremely vital for human survival (7). It plays a major role in the social, psychological, and physical development of an individual. Education enlightens people and enables them to create a better life for themselves. Furthermore, the World Bank

\section{Corresponding author:}

Ologan Eloho Ukochovwera, Ekiti State University, Nigeria. Tel: +234.7068886657, E-mail: eloho206@yahoo.com Received: June 02, 2021, Accepted: August 14, 2021, Published: September 2021

iThenticate screening: September 02, 2021, English editing: September 10, 2021, Quality control: September 12, 2021

Ethics approval: Ethics Committee of the Ekiti State University (Ref: ORD/AD/EAC/20/047)

(C) 2021 The Authors. This is an open access article under the terms of the Creative Commons Attribution-NonCommercialNoDerivs License, which permits use and distribution in any medium, provided the original work is properly cited, the use is non-commercial and no modifications or adaptations are made. 
(8) opined that literacy improvement enhances regional and household development. Education, starting from home, is important because home is acknowledged as the bedrock of society worldwide (9).

This practice could be harmful and result in recurrent infections, complications/difficulty in passing out urine and menstrual flow, chronic pain, infertility, development of cyst, scarring, abscesses, risk of prolonged obstructed labor, tissue damage, complications during childbirth, fatal bleeding, HIV/AIDS, shock, etc. FGM is done by adults on adults, young women, and children (10); hence, the perpetrators and victims should be enlightened on the dangers of such procedure and encouraged the discontinuation of the practice by using means that both literates and illiterates would understand (11). It is essential to train adults and raise their awareness about FGM since they are the traditionalists that carry out the act. Andragogy is the engaging of adults in the systems that are applicable presently, enlighten them to gain new knowledge, skills, attitudes, or values. Since it requires learning beyond traditional schooling, some basic literacy for personal fulfillment is needed (12). Adult literacy stands out because it is based on the assumed philosophy that learners' tendency to learn makes them take responsibility for the learning with the hope that it would respond to their needs (13). Andragogy could take place with the help of health professionals in rural areas by raising awareness about preventing FGM (14). This would be another effective way to sensitize the members of the community because health care providers are in contact with patients, are the first to be called when in need of health advice, and are at the heart of the community, and thus they play a vital role in treatment and counseling (15). FGM poses immediate and long-term health consequences on the physical, reproductive, and emotional health of women and girls. It has been observed that most women are not aware of the health risk associated with FGM during antenatal and postnatal clinic sessions and are not encouraged to stop the maladaptive practice (16). The mass media, including television, radio, newspapers, films, and social media, are pivotal to the entertainment, information, and education of the masses regarding different issues; therefore, FGM should not be left out (17). The strength of social media cannot be overemphasized as it is the creator and distributor of information and can be used for health promotion, disease prevention, and social orientation (18).

The general objective of this research was to determine the impact of education on the awareness about FGM. The specific objectives were: (1) to determine the difference between FGM practice in rural and urban areas, (2) to assess the effect of education on FGM awareness, (3) to identify the campaign programs commonly adopted against FGM in Osun State, and (4) to determine the relationship between parents' level of education and health and media campaigns, health programs, and FGM in Osun State.

\section{Material and Methods}

\subsection{Research Design and Setting}

This cross-sectional study was conducted in Osun State, Nigeria, from February 2020 to March 2021. The research population consisted of entirely married females drawn from all the 30 local government areas of Osun State.

\subsection{Sampling}

The respondents for this study comprised 371 women selected using a multi-stage sampling procedure, and two LGA's each selected from the 3 senatorial districts in Osun State for the first stage using a simple random sampling technique. The stratified random sampling technique was used for the second stage, where two towns from each of the chosen LGA'S (urban and rural) were selected, while 40 women were selected using a simple random sampling technique for the third stage. This method is best suited because it shows no bias in the selection of women most affected by this practice.

\subsection{Instrument}

The study adopted the "Questionnaire on Andragogy and Female Genital Mutilation (QAFGM)" to elicit information from the respondents in two sections of A and B. Section A consisted of the biodata of the respondents while Section B is comprised of questions from the purpose of the study highlighted above using the 4-points Likert scale. This study was considered reliable using the test-retest method, where questionnaires were administered to 20 respondents that were not part of the original sample. Moreover, two weeks after being re-administered to that same group, the results were analyzed and correlated using Pearson's product-moment correlation statistic and a reliability coefficient of 0.79 was obtained.

\subsection{Statistical Analyses}

Descriptive and inferential statistics were used to analyze the data. Standard deviation, mean, percentage, and frequency were used to analyze the research questions. Inferential statistics of the Pearson product-moment 
http://www.ephysician.ir

correlation and independent-samples t-test were used to examine research hypotheses. All hypotheses were tested at a significant level of 0.05 .

\subsection{Ethical Considerations}

This research was approved by the Ethics Committee of the Ekiti State University (Ref: ORD/AD/EAC/20/047). Informed consent was obtained from the participants, and their participation was voluntary. No harm as the psychological state of the victims of FGM was put into consideration. Confidentiality and anonymity were granted to those who requested them.

\section{Results}

\subsection{Descriptive Findings}

The prevalence of FGM in Osun State, Nigeria, is presented in Table 1. According to this table, out of 371 respondents, $64.2 \%$ believed that in their community FGM is practiced, $46.6 \%$ believed that the practice of FGM is widely accepted in their community, and $69.5 \%$ believed that both literate and illiterate members of the society practice FGM. Similarly, $69.5 \%$ of the respondents believed that the practice of FGM is widespread in Osun State. The table further showed that $46.6 \%$ of the respondents believed that the practice of FGM is unusual in urban areas, and $66 \%$ reported having circumcised female family members. Moreover, it was discovered from the table above that $73 \%$ of the respondents believed that the practice of FGM is high in rural areas and $50.1 \%$ reported that the use of FGM in their families. In addition, 53.6\% conceded that FGM is done in open and public settings and finally, $55.5 \%$ of the respondents agreed that people do not worry about the consequences of FGM. Setting 2.60 as the mean cut-off point, the mean scores of Items 1, 3, 4, 6, 7, and 10 (presented on the table) is above the mean cut-off point; whereas, the mean scores of Items 2, 5, 8, and 9 are below the mean cut-off point. The implication is the moderate prevalence of FGM in Osun State, Nigeria. As Table 2 shows, the media campaign is the most common FGM campaign in Osun State.

Table 1. Practice level of Female Genital Mutilation in Osun State, Nigeria*.

\begin{tabular}{|l|l|l|l|l|l|l|l|l|}
\hline Questionnaire items & $\mathrm{N}$ & $\mathrm{A}$ & $\mathrm{D}$ & $\mathrm{M}$ Sean & SD & Remark \\
\cline { 2 - 7 } & & $\mathrm{f}$ & $\%$ & $\mathrm{f}$ & $\%$ & & \\
\hline $\begin{array}{l}\text { In my community Female genital mutilation is } \\
\text { practiced }\end{array}$ & 371 & 238 & 64.2 & 133 & 35.8 & 2.64 & 0.480 & High \\
\hline In my community, FGM practice is widely accepted & 371 & 173 & 46.6 & 198 & 53.4 & 2.47 & 0.500 & Low \\
\hline $\begin{array}{l}\text { literate and illiterate members of the society practice } \\
\text { female genital mutilation }\end{array}$ & 371 & 258 & 69.5 & 113 & 30.5 & 2.70 & 0.461 & High \\
\hline $\begin{array}{l}\text { The practice of Female genital mutilation is very } \\
\text { common in Osun state }\end{array}$ & 371 & 258 & 69.5 & 113 & 30.5 & 2.70 & 0.461 & High \\
\hline $\begin{array}{l}\text { In metropolitan areas Female genital mutilation is } \\
\text { rarely practiced }\end{array}$ & 371 & 173 & 46.6 & 198 & 53.4 & 2.47 & 0.500 & Low \\
\hline $\begin{array}{l}\text { Do you have female family members that are } \\
\text { circumcised? }\end{array}$ & 371 & 245 & 66 & 126 & 34 & 2.66 & 0.474 & High \\
\hline $\begin{array}{l}\text { The practice of Female genital mutilation is high in } \\
\text { rural areas }\end{array}$ & 371 & 271 & 73 & 100 & 27 & 2.73 & 0.444 & High \\
\hline In your family is Female genital mutilation practiced? & 371 & 186 & 50.1 & 185 & 49.9 & 2.50 & 0.501 & Low \\
\hline $\begin{array}{l}\text { Female genital mutilation is done in open and public } \\
\text { settings }\end{array}$ & 371 & 199 & 53.6 & 172 & 46.4 & 2.54 & 0.499 & Low \\
\hline $\begin{array}{l}\text { People do not worry about the consequences of Female } \\
\text { genital mutilation }\end{array}$ & 371 & 206 & 55.5 & 165 & 44.5 & 2.63 & 0.668 & High \\
\hline
\end{tabular}

$*$ Mean Cut Off $=2.60$

Table 2. The most commonly used campaign Program against Female Genital Mutilation in Osun State

\begin{tabular}{|l|l|l|l|l|}
\hline Campaign Program & $\mathrm{n}$ & Mean & SD & Rank \\
\hline Media Campaign & 371 & 15.68 & 3.700 & $1^{\text {st }}$ \\
\hline Program on Adult education & 371 & 13.33 & 4.121 & $2^{\text {nd }}$ \\
\hline Health Campaign & 371 & 10.49 & 3.919 & $3^{\text {rd }}$ \\
\hline
\end{tabular}




\subsection{Hypothesis Test Results}

According to Pearson product-moment correlation test (Table 3), the relationship between adult education level and the practice of FGM was not significant in Osun State $(p=0.274)$. Meanwhile, the relationship between health campaigns and FGM practice was significant $(\mathrm{p}<0.0001)$. The results showed a significant relationship between the media campaign level and FGM practice $(\mathrm{p}<0.0001)$. Table 3 also reveals that the relationship between parents' level of education and FGM was significant $(\mathrm{p}<0.0001)$. Furthermore, no significant difference was observed between FGM practices in the rural and urban areas $(\mathrm{p}=0.631)$.

Table 3. Relationship between Adult Education Program and Female Genital Mutilation Practice in Ekiti State

\begin{tabular}{|c|c|c|c|c|c|}
\hline \multicolumn{2}{|l|}{ Variables } & Mean & SD & $\mathrm{n}$ & $\mathrm{p}$-value \\
\hline \multirow{2}{*}{$\begin{array}{l}\text { Relationship between Adult Education } \\
\text { Program and Female Genital } \\
\text { Mutilation Practice in Osun State }\end{array}$} & Program on adult education & 13.33 & 4.121 & \multirow[t]{2}{*}{371} & \multirow[t]{2}{*}{0.274} \\
\hline & Practice of Female Genital Mutilation & 28.48 & 9.599 & & \\
\hline \multirow{2}{*}{$\begin{array}{l}\text { Health Campaign level and the Female } \\
\text { Genital Mutilation in Osun State }\end{array}$} & Health Campaign & 10.49 & 3.919 & \multirow{2}{*}{371} & $<0.0001$ \\
\hline & Practice of Female Genital Mutilation & 28.48 & 9.599 & & \\
\hline \multirow{2}{*}{$\begin{array}{l}\text { Media Campaign level and Female } \\
\text { Genital Mutilation practice in Osun } \\
\text { State }\end{array}$} & Media Campaign & 15.68 & 3.700 & \multirow[b]{2}{*}{371} & $<0.0001$ \\
\hline & Practice of Female Genital Mutilation & 28.48 & 9.599 & & \\
\hline \multirow{2}{*}{$\begin{array}{l}\text { Level of Parents' Education and } \\
\text { Female Genital Mutilation in Ekiti } \\
\text { State }\end{array}$} & Educational Qualification & 3.82 & .987 & \multirow[b]{2}{*}{371} & $<0.0001$ \\
\hline & Female Genital Mutilation Practice & 28.48 & 9.599 & & \\
\hline \multirow[t]{2}{*}{ Female Genital Mutilation Practice } & Rural & 28.86 & 10.636 & 106 & \multirow[t]{2}{*}{0.631} \\
\hline & Urban & 28.33 & 9.168 & 265 & \\
\hline
\end{tabular}

a: Pearson product-moment correlation test; b: Independent-samples t-test.

\section{Discussion}

\subsection{Prevalence of FGM}

According to the research outcomes, there is moderate FGM prevalence in Osun State. Although it is still at an unacceptable rate, this prevalence is slowly reducing. The outcome of the study was negated by Blessing (19), who reported its high preponderance with $77 \%$ of circumcised women between the ages 15-49. This discrepancy could be attributed to campaign programs organized by the government over the years. This shows that if more work is put into these campaign programs, the fight against FGM could be fruitful in this state.

\subsection{Most Common Campain against FGM}

The findings revealed media accounts for the majority of campaigns against FGM in Osun State. Dare et al. (20) believe that the use of various campaigns and counseling methods could contribute to the eradication of such harmful practices and raise awareness about FGM which, in turn, help women desist, prevent, and fight against FGM.

\subsection{Attitude towards Eradication of FGM}

Results from this study showed that people had a positive opinion towards and supported the eradication of FGM in Osun State. Some respondents acknowledged FGM as a useless practice, which is accompanied by risks to women. They all wanted it to be stopped for different reasons, different experiences, and different educational levels. According to Okeke et al. (21), highly educated women were not in support of this practice; whereas, low educated women felt the practice was necessary. Gbadebo et al. (22) disclosed that circumcised women were in support of this practice.

\subsection{Connection of Parents' Educational Attainment to Health, Media Campaign, and FGM}

Results from this study showed low administration of adult education programs on FGM in Osun State and a lack of a significant relationship between adult education and FGM practice in the state. Olatunbosun (23) opined that FGM occurs among literates and illiterates but with a higher prevalence among the latter group. It was revealed that the least used campaign method against FGM in Osun State was the health campaign and the relationship between health campaign and FGM practice was negative. This shows an inverse relationship between a higher level of education and the prevalence of FGM. This corroborates the research by Oyinade and Darmola (24), where they documented that a higher educational level of parents is accompanied by their further tendency towards acquiring 
health education. They also established that educated parents would be less disposed to having their daughters undergo circumcision because they are more aware of the damages of such practice through health education. It was further revealed that educated parents are less inclined to have their daughters undergo FGM because they are more likely to be exposed to health education about the practice. Moreover, Odujurin and Akintoye (25) stated that highly educated parents are not likely to circumcise their daughters but illiterate parents had a high tendency to and that most circumcised daughters were from circumcised mothers. Adeyinka et al. (26) also acknowledged that parents with a high level of education would not practice FGM. According to the findings of this study, the media campaign is the most used form of a campaign to combat FGM in Osun State. The study revealed a relationship between media campaigns and FGM in Osun State, showing that the level of the media campaigns was not as high as expected, and the higher the media campaign level the lower the practice of FGM. This is in line with the submission of Ahmadi (13), who believed that every media content has the power to influence the attitude and behavior of its audience. Hence if swindled properly has the power to change long-aged cultural beliefs and practices that are detrimental to one's well-being since human behavior, as well as culture, is dynamic.

\subsection{Discrepancy in Prevalence of FGM}

This study revealed that no significant difference ensued in FGM in rural and urban areas of Osun state even though it was assumed that the reverse would be the case. This signifies that the prevalence of FGM in rural and urban areas of Osun State is the same. The DHS 2013 findings are by this study where it was discovered that the practice was almost the same in those areas (27). However, this finding was contradicted by Alo and Gbadebo (28), who emphasized the fact that FGM prevailed more in the rural areas than the urban areas and one in the rural areas tended to practice FGM more than those in the urban area.

\section{Conclusions}

Concerning the findings of this study, it is recommended that the government must establish more health care centers in various communities with highly qualified personnel to help curb maladaptive behaviors and cultural practices that pose a threat to the life of the people. Policymakers should put measures in place to ensure that health personnel carry out complete sensitization and raise awareness on the risks of FGM during antenatal and prenatal checkups in hospitals both at the rural and urban centers. The power system should be enhanced because the visual media is a very important part of the media campaign, with regular blackouts the people mostly in the rural areas will have a difficult time assessing information through the visual media. Government should put policies in place to empower the woman through education, health care, which is a major tool for information that in turn will lead to development for the society and stop gender inequality. In addition, women's access and engagement in media should be encouraged and the development of more inclusive campaigns and adult education programs that bring about knowledge promotion, attitudinal and behavioral change, increased community awareness and knowledge of the health hazard associated with FGM practice should be encouraged by the government and NGOs. Taking into consideration the culturally diverse society the government should intensify culturally responsive education and campaign.

\section{Acknowledgments:}

The author thanks all participants of the study and the Ekiti State University, Nigeria.

\section{Conflict of Interest:}

There is no conflict of interest to be declared.

\section{Authors' contributions:}

All authors contributed to this project and article equally. All authors read and approved the final manuscript.

\section{References:}

1) Shetty Priya. Slow progress in ending female genital mutilation. World Health Organization Geneva. Bulletin of the World Health Organization. 2014; 92 (1): 6-7. DOI: 10.2471/BLT. 15.020114. PMid: 24391294, PMCid: PMC3865556

2) World Health Organisation (WHO). Understanding and addressing violence against women. 2010. Available from: http://www.who.int/reproductivehealth/publications/fgm/9789241596442/en/index.html

3) Zurynski, Y., Sureshkumar, P., Phu, A. et Al. Female genital mutilation and cutting: A systematic literature review of health professionals knowledge, attitudes and clinical practice. BMC international Health Human Rights 15, 32. 2015. DOI: 10.1186/s12914-015-0070-y. PMid: 26652275, PMCid: PMC467608 
4) United Nations Children Emergency Funds. Legislative Reform to Support the Abandonment of Female Genital Mutilation/Cutting. 2013.

5) Lazuta, J. 'In Senegal, Reconstructive Surgery for FGM Victims', 26 December, Voice of America. 2012

6) Gage, A. and Van Rossem, R. Attitudes toward the discontinuation of female genital cutting among men and women in Guinea. International Journal of Gynecology \& Obstetrics. 2006; 92 (1): 92-6. DOI: 10.1016/j.ijgo.2005.09.019, PMid: 16269146

7) Mechthild, H. Working and educating for life: Feminist and international perspective on adult education. Rutledge. 2018. DOI: 10.4324/9780429457654, PMid: 30530840 , PMCid: PMC6282766

8) World Bank. World Development Report 2018: Learning to Realise Education's Promise. DOI: 10.1596/978-1-4648-1096-1. PMid: 30325347

9) Nel, N. Starting at home: Caring and social policy. University of California press. 2002.

10) Grumenbaum, E. The female Circumcision Controversy: An Anthropological Perspective, Philadelphia: University of. Pennsylvania Press, 2015. DOI: 10.9783/9780812292510. PMCid: PMC1221840

11) Shilubane, T.T. Empowerment of rural women of Mopani through adult illiteracy programs. University of South Africa. 2007

12) Khalid, M., Erradi, M. Between Pedagogy and Andragogy: Definitions and Concepts. Source title: Research Anthropology on Adult Education and the Development of Life Long Learners. 2021: 139-176. DOI: 10.4018/978-1-7998-8598-6.ch007

13) Ahmadi, \& Amir, B.A. An analytical approach to female genital mutilation in West Africa. International Journal of Women's Research. 2013; 3(1): 37-56.

14) Barnawi, Najla. "The Effects of a Digital Educational Intervention On Undergraduate Nursing Students' Attitudes, Knowledge And Self-Efficacy With Female Genital Cutting" (2018). Graduate Dissertations and Theses. 48. Available from: https://orb.binghamton.edu/dissertation_and_theses/48

15) Delamaire, M. and G. Lafortune. "Nurses in Advanced Roles: A Description and Evaluation of Experiences in 12 Developed Countries", OECD Health Working Papers, No. 54, OECD Publishing. 2010. DOI: $10.1787 / 5 \mathrm{kmbrcfms} 5 \mathrm{~g} 7$-en.

16) Boyle, Elizabeth \& Preves, Sharon. National Politics as International Process: The Case of Anti-FemaleGenital-Cutting Laws. Law \& Society Review. 2000; 34: 703. DOI: 10.2307/3115141.

17) Servaes, J. Approaches to development communication. Paris. UNESCO. 2002.

18) World Health Organisation (WHO). From innovation to implementation. eHealth in the WHO region. Geneva, Switzerland: World Health Organisation. 2016.

19) Blessing Uchenna Mberu. "Female genital mutilation/cutting in Nigeria: A scoping review" Evidence to End FGM/C: Research to Help Women Thrive. New York: Population Council, 2017. Available from: http://www.popcouncil.org/uploads/pdfs/2017RH_FGMC-NigeriaScopingReview.pdf

20) Dare, F.O., Oboro, V.O., Fadiora, S.O., Orji, E.O., Sule-Odu, A.O. \& Olabode, T.O. Female genital mutilation: An analysis of 522 cases in South-western Nigeria. International Journal of Obstetrics and Gynaecology, 2004; 24(3): 281-3, DOI: 10.1080/01443610410001660850. PMid: 15203627

21) Okeke, E.C \& Okonrokwo, H.O. Female genital mutilation: Perceptions and beliefs in a Nigerian rural community. African Anthropology. 2012; 6(1): 72-81.

22) Gbadebo BM, Afolabi RF, Adebowale AS. Female circumcision in Nigeria and attitudes towards its discontinuation. Afr J Med Med Sci. 2015; 44(4):343-54.

23) Olatunbosun, O.A. Female genital mutilation: A model for research on sexual and reproductive rights. African Journal of Reproductive Health. 2015; 4(2): 14-6.

24) Oyinade, B. \& Daramola, I. 'Gender, Media, and Politics: A Case Study of Nigeria', Singaporean Journal of Business Economics, and Management Studies, 2013; 1(10): 25-33

25) Odujinrin, O.M., Akintoye, C.O. \& Oyediran, M.A. A study on female circumcision in Nigeria. West Africa Journal of Medicine. 2011; 8(3): 183-92

26) Adeyinka, A.R., Adedotun, O.O. \& Asabi, O. Knowledge and practice of female circumcision among women of reproductive ages in Southwest, Nigeria, IOSR Journal of Humanities and Social Science (JHSS), 2012; 2(3): 38-45. DOI: 10.9790/0837-0233845

27) Nigeria Demographic and Health Survey 2013 (DHS 2013). Maryland: Available from https://dhsprogram.com/pubs/pdf/FR293/FR293.pdf

28) Alo, O.A. \& Gbadebo, B. Intergenerational attitude changes regarding female genital cutting in Nigeria. Journal of Women's Health, 2011; 20(1): 1655-61. DOI: 10.1089/jwh.2010.2610, PMid: 21919739 